UDC 543.064: 616-074

DOI: $10.21668 /$ health.risk/2018.2.14.eng

Read

\title{
METHODICAL AND PRACTICAL ASPECTS RELATED TO TOTAL MERCURY DETERMINATION IN WHOLE BLOOD, URINE AND HAIR WITH MASS-SPECTROMETRY WITH INDUCTIVELY COUPLED PLASMA
}

\author{
T.S. Ulanova ${ }^{1,2}$, E.V. Stenno ${ }^{1}$, G.A. Veikhman ${ }^{1,3}$, A.V. Nedoshitova ${ }^{1}$ \\ ${ }^{1}$ Federal Scientific Centerfor Medical and Preventive Health Risk Management Technologies, 82 Monastyrskaya \\ Str., Perm, 614045, Russian Federation \\ ${ }^{2}$ Perm National Research Polytechnic University, 29 Komsomolskiy avenue, Perm, 614990, Russian Federation \\ ${ }^{3}$ Perm State Pharmaceutical Academy, 2 Polevaya Str., Perm, 614081, Russian Federation
}

A precise, selective, and sufficiently sensitive quantitative procedure for determining chemicals contents in environmental objects and a human body is often a key to correct health risk assessment.

The authors describe optimized conditions for analyzing whole blood, urine, and hair samples used for determining total mercury contents with mass-spectrometry with inductively coupled plasma (sampling, samples storage, preparations to analysis, instrumental settings of a device, analysis conditions).

We quantitatively determined mercury in blood, urine, and hair samples with Agilent 7500cx mass spectrometer with octopole reaction/collision cell (Agilent Technologies, USA). To prepare for whole blood samples analysis, we applied acid dilution in concentrated nitric acid with consequent centrifuging. Urine samples were directly analyzed after 1/10 (V/V) dilution with $1 \%$ nitric acid solution. The suggested conditions of conventional biological media analysis applied in total mercury determining with mass spectrometry with inductively coupled plasma allow to determine the element in blood within 0.5-100 $\mu \mathrm{g} / \mathrm{l}$ with measurement error being equal to $29.4 \%$; in urine, within $0.4-100 \mu \mathrm{g} / \mathrm{l}$ with measurement error being equal to $24.2 \%$; in hair, within $0.001-100$ $\mu \mathrm{g} / \mathrm{l}$ with measurement error being equal to $22.4 \%$. When validating the procedure, we found the following limits of detection (LOD): $0.0015 \mu \mathrm{g} / \mathrm{l}$ for blood; $0.012 \mu \mathrm{g} / \mathrm{l}$, for urine; and $0.003 \mu \mathrm{g} / \mathrm{l}$, for hair.

Correctness of the results was confirmed by examination of standards blood samples SERONORM (Sero AS, Norway) blood L1 (LOT 1103128), L2 (LOT 1103129), L3 (LOT 1112691), urine samples Seronorm ${ }^{\text {TM }}$ (Sero AS, Norway) urine (LOT 0511545), and hair samples Reference Material in Human Hair (IAEA-086, Vienna, Austria).

Total mercury contents in children's blood was determine within 0.02-1.2 $\mu \mathrm{g} / \mathrm{l}$; within $0.45-0.8 \mu \mathrm{g} / \mathrm{l}$ in urine. Contents in urine taken from exposed adults amounted to 0.65-8.2 $\mu \mathrm{g} / \mathrm{l}$, and to 0.29-0.49 $\mu \mathrm{g} / \mathrm{l} \mathrm{in} \mathrm{hair}$.

Key words: mercury, quantitative determination, mass spectrometry, inductively coupled plasma, whole blood, urine, hair, acid dilution.

Research based on human biomonitoring (HBM) is attracting considerable attention these days. By measuring concentra- tions of chemicals or their metabolites in biological materials researchers can perform a complex assessment of exposure

(C) Ulanova T.S., Stenno E.V., Veikhman G.A., Nedoshitova A.V., 2018

Tat'yana S. Ulanova - Doctor of Biological Sciences, Professor, head of Chemical and Analytical Research Department (e-mail: ulanova@,fcrisk.ru; tel.: +7 (342) 233-10-37). 37).

Elena V. Stenno - Head of Element Analysis Laboratory (e-mail: stenno@fcrisk.ru; tel.: +7 (342) 233-10-

Galina A. Veikhman - Candidate of Pharmaceutical Sciences, Leading Researcher at Element Analysis Laboratory (e-mail: veikhman_ga@mail.ru; tel.: +7 (342) 233-10-37).

Anna V. Nedoshitova - Leading Chemist at Element Analysis Laboratory (e-mail: nav@,fcrsk.ru; tel.: +7 (342) 233-10-37). 
under different introduction; they can also determine speed of absorption, metabolism, and excretion. The WHO recommends various procedures and techniques aimed at determining concentrations of persistent and bioaccumulating contaminants, and requirements to such procedures and techniques are becoming stricter in order to achieve better comparability and validity of HBM results [1].

Mercury is now not so widely applied as it used to be; none the less, it is still a global contaminant. Mercury is a heavy metal, a cumulative poison, and it belongs to chemicals with the 1st hazard degree (CAS 7439-97-6). Toxicity of mercury for people is related to erythrocytes agglutination, inhibition of enzymes, and disorders in protein metabolism. Mercury enters a body via various ways as it can be inhaled, introduced orally or transdermally; it is then detected in all organs and tissues of a human body [2-4]. Mercury concentrations in blood allow to estimate recent or current contamination with all the types of this metal; mercury concentrations in urine help to estimate current or recent contamination with elemental and inorganic mercury; an analysis performed on hair allows to determine contamination with organic mercury which occurred during various periods of time $[1,5]$.

Table 1 below contains reference mercury concentrations in various biological media as per data obtained from scientific literature 1.

L.M. Karimova, T.K. Larionova, and G.R. Basharova think that maximum mercury concentration which doesn't lead to shifts in hematologic, biochemical, and
Table 1

Reference mercury concentrations in blood, urine $(\mu \mathrm{g} / \mathrm{l})$ and hair $(\mu \mathrm{g} / \mathrm{g})$

\begin{tabular}{|l|c|c|c|}
\hline \multicolumn{1}{|c|}{$\begin{array}{c}\text { Author / analysis } \\
\text { technique }\end{array}$} & $\begin{array}{c}\text { Blood, } \\
\mu \mathrm{g} / \mathrm{l}\end{array}$ & $\begin{array}{c}\text { Urine, } \\
\mu \mathrm{g} / \mathrm{l}\end{array}$ & $\begin{array}{c}\text { Hair, } \\
\mu \mathrm{g} / \mathrm{g}\end{array}$ \\
\hline WHO, 2010 [5] & $5-10$ & $5,6(<10)$ & $<10$ \\
\hline Tits N.U.,(AAC) [3] & $0,6-59$ & $<20$ & $<15$ \\
\hline Kaletina N.I. [4] & $3-11$ & 2 & $0,5-1,5$ \\
\hline Skal'niy A.V. [2] & - & $0,1-2,0$ & $0,05-2,0$ \\
\hline Schulz C. (ICP-MS) [6] & $0,8-1,0$ & $0,4-0,7$ & - \\
\hline $\begin{array}{l}\text { ALS Scandinavia (ICP- } \\
\text { MS) [7] }\end{array}$ & $0,46-7,5$ & $0,14-4,2$ & $0,05-0,93$ \\
\hline $\begin{array}{l}\text { Goulle J.P. (ICP-MS) } \\
\text { [8] }\end{array}$ & $0,94-8,13$ & $0,14-2,22$ & $0,31-1,66$ \\
\hline
\end{tabular}

immunologic parameters amounts to $1 \mu \mathrm{g} / \mathrm{l}$ [9]. Methodical guidelines for early diagnostics of toxic mercury effects in low intensity doses in children (MG 2000/140) approved by the RF Public Healthcare Ministry set forth background mercury concentration in children's morning urine which is equal to $0.56 \pm 0.07 \mu \mathrm{g} / 1$ (the range is $0.3-0.9 \mu \mathrm{g} / \mathrm{l})^{1}$. The Commission on HBM of the German Federal Environmental Agency offers reference values of HBM-1 and HBM-2 which amount to 5 and $15 \mu \mathrm{g} / 1$ for mercury in blood, and to 7 and $25 \mu \mathrm{g} / \mathrm{l}$ in urine correspondingly [1]. HBM-1 is such a concentration in a biological material below which there isn't any health risk. When BHM-2 concentration is reached, it causes an elevated risk of adverse influence, and toxic effects should be eliminated immediately. Obviously, considerable differences in the given values and the data which can be found in Table 1 are related not only to peculiarities of examined populations, but also to application of different analysis techniques.

To detect mercury in biological media, we need highly sensitive and highly

\footnotetext{
${ }^{1}$ MG 2000/140. Metodika rannei diagnostiki i prognozirovaniya techeniya toksicheskogo deistviya rtuti v dozakh maloi intensivnosti u detei: metodicheskie rekomendatsii № 2000/140 ot 28.05.2001 g. [A procedure for early diagnostics and prediction of toxic effects exerted on children by mercury in low intensity doses: Methodical guidelines approved on May 05, $2001 \mathrm{~N}$ 2000/140]. Hippocratic.ru: Medical information source. Available at: http://www.hippocratic.ru/medtext1/medtext 8833.htm (23.01.2018).
} 
efficient analysis techniques. They are primarily mass-spectrometry with inductively coupled plasma (ICP-MS) and electrothermal atomic-absorption spectrometry $(\mathrm{ET}-\mathrm{AAS})^{2}$ [10]. Atomic-absorption spectrometry as a technique for mercury determination is usually applied via absorption of cold mercury vapor with specific mercury-hydride detachable devices (MHDD) for atomic-absorption spectrometers or with mercury analyzers [11]. Atomic absorption of cold vapor is highly sensitive (detection limits are similar to those of ICP-MS) and selective due to distillation of elemental mercury vapor from a sample matrix. At the same time, N.B. Ivannko et al. state [12] that such techniques are still inferior to ICP-MS due to their much lower productivity. In 2003 Methodical Guidelines No. 4.1.1483-03 were approved and became valid in the RF; these guidelines fix procedures for determining concentrations of chemical elements, including mercury, in biological substrates via ICP-MS technique $^{3}$. Ranges within which mercury is detected in various biological media and biologically active additives amount to $0.1-10 \mu \mathrm{g} / 1$, determination inaccuracy is $40 \%, 10-100 \mu \mathrm{g} / 1$, determination inaccuracy is $20 \%$, detection limit is equal to 0.01 $\mu \mathrm{g} / \mathrm{l}$.

But still, when we perform quantitative determination of mercury via ICP-MS, we often face certain difficulties which are related to physical and chemical properties of the element. Mercury is a liquid metal of silver color, volatile, and resistant to water and air. High volatility of mercury calls for a sample preservation at a stage when it is being taken. Mercury has a very high ionizing potential which is equal to $10.44 \mathrm{eV}$, and it imposes substantial limits on efficiency of its ionization in plasma during a mass-spectrometry analysis and results in low sensitivity of the technique. Besides, another serious problem is related to a so called "memory effect". This disturbing action is caused by a great difficulty which we face when we try to wash residual quantities of mercury off feeding equipment, a spray chamber, burner, and interface parts of a mass spectrometer $[12,13]$.

It turned out to be rather difficult to apply MG $4.1 .1483-03^{3}$ in clinical and laboratory practices to determine mercury contents as this procedure didn't fix precise parameters for samples preparation and analysis conditions.

Therefore, all the above mentioned made us choose our research goal which was to optimize conditions for a routine biological media analysis aimed at determining overall mercury contents via massspectrometry with inductively coupled plasma.

Data and methods. We performed quantitative determination of mercury in blood, urine, and hair samples with Agilent $7500 \mathrm{cx}$ mass spectrometer with an octopole reaction/collision cell (Agilent Technologies, the USA) with 27.12 millihertz transistor oscillator. To introduce samples, we applied a two-channel Scott spray chamber which was cooled down to $2{ }^{\circ} \mathrm{C}$

\footnotetext{
${ }^{2}$ MG 4.1.1470-03. Atomno-absorbtsionnoe opredelenie massovoi kontsentratsii rtuti v biomaterialakh (moche, volosakh, kondensate al'veolyarnoi vlagi) pri gigienicheskikh issledovaniyakh [Atomic-adsorption determination of mercury mass concentrations in biological materials (urine, hair, and alveolar liquid condensate) in hygienic research]. CODEX: Electronic data fund for legal and technical regulatory documentation. Available at: http://docs.cntd.ru/document/1200034849 (23.01.2018).

${ }^{3}$ MG 4.1.1483-03. Opredelenie soderzhaniya khimicheskikh elementov v diagnostiruemykh biosubstratakh, preparatakh i biologicheski aktivnykh dobavkakh metodom mass-spektrometrii s induktivno svyazannoi argonovoi plazmoi issledovaniyakh [Determination of chemical elements in diagnosed substrates, preparations, and biologically active additives via mass-spectrometry with inductively coupled argon plasma]. CODEX: Electronic data fund for legal and technical regulatory documentation. Available at: http://docs.cntd.ru/document/1200032531(23.01.2018).
} 
with a Peltier device (thermoelectric cooler). A sample was fed into the spray chamber at a speed equal to $0.4 \mathrm{ml} / \mathrm{min}$. The mass-spectrometer was equipped with Fassel plasma torch, its injector tube diameter being $2.5 \mathrm{~mm}$. We used liquid argon with high purity equal to $99.998 \%$ (TC-2114005-00204760-99). Maximum speed of argon flow amounted to $20 \mathrm{l} / \mathrm{min}$, pressure in the gas-feeding channel was equal to $700 \pm 20 \mathrm{kPa}$, plasma temperature was 8000-10000 K. The process of the analysis was automated with G3160B autosampler (Germany).

To adjust the device receptiveness, we applied ${ }^{7} \mathrm{Li},{ }^{59} \mathrm{Co},{ }^{89} \mathrm{Y}$, and ${ }^{205} \mathrm{Tl}$ solution in $2 \%$ nitric acid with each element concentration being equal to $1 \mu \mathrm{g} / 1$ (Tuning Solution, the USA). We chose gaseous helium with high purity $(99.995 \%)$ as a gas-reagent. To make Internal Standards (IS) solutions, we used a complex standard solution of ${ }^{209} \mathrm{Bi},{ }^{73} \mathrm{Ge},{ }^{115} \mathrm{In},{ }^{6} \mathrm{Li},{ }^{45} \mathrm{Sc}$, ${ }^{159} \mathrm{~Tb},{ }^{89} \mathrm{Y}$ with their concentration being equal to $10 \mu \mathrm{g} / \mathrm{l}$ in a water solution of nitric acid (Internal Standard Mix, the USA), as well as a standard ${ }^{103} \mathrm{Rh}$ solution with its concentration being $10 \mu \mathrm{g} / 1$ in $2 \%$ water solution of hydrochloric acid (Rhodium Internal Standard, the USA). We applied highly pure nitric acid with $\mathrm{As}, \mathrm{Cd}, \mathrm{Cu}$, $\mathrm{Mn}, \mathrm{Pb}, \mathrm{Sr}$, and $\mathrm{V}$ contents $\leq 0.01 \mathrm{mg} / \mathrm{kg}$; $\mathrm{Cr}$ and $\mathrm{Ni}$ contents $\leq 0.02 \mathrm{mg} / \mathrm{kg}$; $\mathrm{Tl}$ and $\mathrm{Zn}$ contents $\leq 0.05 \mathrm{mg} / \mathrm{kg}$ (Nitric acid $69 \%$, Sigma-Aldrich, the USA).

To dilute, we applied deionized water with its specific resistance being equal to 18.22 Mom·cm which was purified with Milli-Q Integral system (Millipore SAS, France). All the laboratory dishes made of glass, teflon, and polypropylene, were washed in Elmasonic $\mathrm{S} 100 \mathrm{H}$ ultrasound cleaner (Germany) at $45^{\circ} \mathrm{C}-50^{\circ} \mathrm{C}$ as per the following procedure: $3-4$ times washing in distilled water, each lasting 10 minutes after which water was changed; then 30 minutes washing in nitric acid diluted with distilled water in a ratio 1:5; after that the dishes were washed with $2-3 \%$ hydrochloric acid solution or with $1 \%$ nitric acid solution containing $5 \mu \mathrm{g} / \mathrm{l}$ of auric chloride.

A substantial stage in chemicalanalytical research is a sample taking and storage, especially when we examine volatile elements. Thus, to prevent losses of mercury during its transportation and storage, it is necessary to freeze samples or to add auric chloride (III) solution into them. To add $\mathrm{AuCl}_{3}$ to samples, we should apply reaction/collision cells, because chlorine ions cause interferences during determination of vanadium, arsenic, and selenium. To achieve efficient ionization of mercury in plasma and to increase receptiveness of a mass spectrometer, it is important to preset power of a frequency generator at 1500-1600 Wt, and a distance between a burner and a selective cone should be about 7-7.5 $\mathrm{mm}$. Prior to an analysis, the device was adjusted in No Gas mode (without a gas-reagent); its receptiveness was checked, as well as background levels, and levels of secondary oxide and doubly charged ions; then the device was switched into Reaction mode.

Before starting an analysis, we made sure that helium had filled all the feeding channels and the reaction cell at a speed equal to $10 \mathrm{ml} / \mathrm{min}$; after that, the device remained untouched for 30 minutes for stabilization.

To prepare calibration solutions, we applied a standard solution of mercury ions with their concentration being $10 \mathrm{mg} / \mathrm{l}$ in $5 \%$ solution of nitric acid (Calibration Standard 2A - HG, the USA).

A specific order in which calibration solutions and the samples themselves are measured is a way to minimize "memory 
effect": first, actual samples with low contents of mercury are fed into plasma, and then calibration solutions follow, starting from one with the lowest concentration and then proceeding with ones with higher concentrations. At present, the highest peak of a calibration graph which we achieved during our research on mercury contents in samples doesn't exceed 1.0 $\mu \mathrm{g} / \mathrm{l}$; it minimizes the device contamination and, consequently, "memory effects". Our calibration graph was designed as per the following points: $0.0 ; 0.1 ; 0.5 ; 1.0 \mu \mathrm{g} / 1$ (Figure 1).

To obtain precise and authentic results, it is necessary to achieve the lowest device background level possible. As we can see from the calibration graph on Figure 1, a concentration which is equivalent to the background (BEC) doesn't make any contribution into analysis results. Correlation coefficient $r$ is equal to 0.9995 , and the detection limit of the device amounts to $0.00478 \mu \mathrm{g} / \mathrm{l}$.

Determination of an optimal element of Internal Standard (IS) is a technique which allows to level off matrix in- fluences exerted by a saturated structure of blood matrix, shifts in a device receptiveness during an analysis, differences in densities of calibration solutions and examined ones, and low ionization degree of ions which are being determined. To do that, we took blood samples with certified mercury contents and prepared them via adding a solution of complex internal standard. Minimal inaccuracies in determining mercury in blood within various concentration ranges were detected when ${ }^{159} \mathrm{~Tb}$ and ${ }^{103} \mathrm{Rh}$ were used as internal standards. A blank experiment also matters a lot, especially when an element is detected in quantities equal to ng/l. Thus, when ${ }^{159} \mathrm{~Tb}$ and ${ }^{103} \mathrm{Rh}$ were applied, a blank sample was equal to approximately $8 \mu \mathrm{g} / \mathrm{l}$, and in case of ${ }^{115} \mathrm{In}$ and ${ }^{209} \mathrm{Bi}$, it was about $18-19 \mu \mathrm{g} / \mathrm{l}$.

Blood. Blood samples were taken from the ulnar vein into vacuum vials made of polypropylene with lithium heparin sputtering (PUTH, China). Samples could be stored in a fridge (from $0^{\circ} \mathrm{C}$ to $4^{\circ} \mathrm{C}$ ) in a hermetically closed vial for 3 days; long-term storage was possible only if they were frozen.

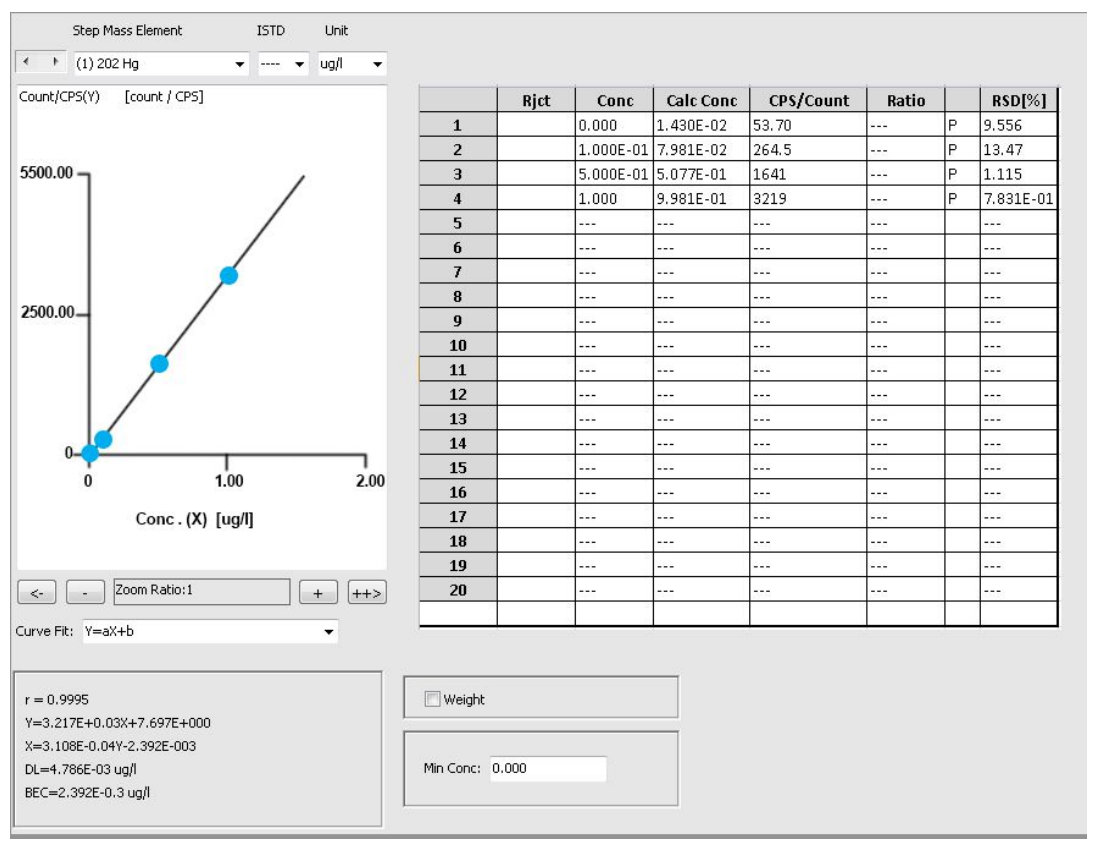

Figure. Calibration graph for mercury ions 
Analysis of spiked samples for blood, urine, and hair samples

\begin{tabular}{|l|c|c|c|c|c|}
\hline \multicolumn{1}{|c|}{ Sample } & LOD in solution & Unspiked sample & Spiked sample & Analysis & $\Delta, \%$ \\
\hline blood (o. 1), $\mu \mathrm{g} / \mathrm{l}$ & 0,0015 & 0,012 & 0,03 & $0,02 / 0,018$ & 10 \\
\hline blood (№. 2), $\mathrm{g} / \mathrm{l}$ & 0,0015 & 0,042 & 0,065 & $0,02 / 0,023$ & 15 \\
\hline urine (№ 1), $\mu \mathrm{g} / \mathrm{l}$ & 0,012 & 0,080 & 0,19 & $0,1 / 0,11$ & 10 \\
\hline urine (№ 2), $\mu \mathrm{g} / \mathrm{l}$ & 0,012 & 0,045 & 1,18 & $1,0 / 1,14$ & 14 \\
\hline hair (№ 1), $\mu \mathrm{g} / \mathrm{g}$ & 0,003 & 0,087 & 0,19 & $0,1 / 0,103$ & 3 \\
\hline hair (№ 2, $\mu \mathrm{g} / \mathrm{g}$ & 0,003 & 0,147 & 0,253 & $0,1 / 0,105$ & 5 \\
\hline
\end{tabular}

To decompose blood samples, an examined sample with its volume being 0.1$0.2 \mathrm{ml}$ was introduced into cone centrifuge plastic screw-top vials; than $0.2-0.4 \mathrm{ml}$ of nitric acid (68\%) and $0.1 \mathrm{ml}$ of a complex internal standard were added; then the mixture was thoroughly stirred. The vials were kept untouched for 2-3 hours; then the volume of the mixture was increased up to 10 $\mathrm{ml}$ and the mixture was centrifuged for 10 minutes at a speed equal to 2700-3000 turns per minute with CLMN-R10-01"Elekon" centrifuge (Russia). The prepared mixture was then put into vials for the consequent mass-spectrometric analysis. At the same time we prepared a blank experiment for each set of samples; blank samples underwent the same preparation and the process included all the reagents which were applied to prepare analyzed samples.

Urine. Samples of morning urine were taken into sterile screw-top polypropylene containers, their volume being 125 ml (F.L.Medical S.r.l., Torreglia, Italy). Urine samples were analyzed after being diluted in a ratio $1 / 10$ with $1 \%$ nitric acid solution: $0.5 \mathrm{ml}$ of urine were added with $4.45 \mathrm{ml}$ of $1 \%$ water solution of $\mathrm{HNO}_{3}$ and $0.05 \mathrm{ml}$ of internal standard solution.

Hair. Hair in its full length was cut off the occipital region in a quantity which allowed to obtain an analytical sample equal to 0.1-0.2 grams. Hair samples were kept in paper packs; they were decomposed in open vials as per the following procedure: hair samples weighing 0.1-0.2 grams were put into cone vials made of polypropylene, their capacity being $15 \mathrm{ml} ; 0.1 \mathrm{ml}$ of IS solution was then added with a doser; then we added 1-2 $\mathrm{ml}$ of concentrated nitric acid, its density being $1.415 \mathrm{~g} / \mathrm{cm}^{3}$; the mixture was kept untouched 3-6 hours until all the hair in it was dissolved; then 1-2 ml of concentrated hydrogen peroxide were added. The vial with the mixture was stirred, kept untouched for 3-4 hours, and then the volume of the mixture was increased to $10 \mathrm{ml}$ with deionized water being added into it and centrifuged for 10 minutes at a speed equal to 2700-3000 turns per minute with CLMN-R10-01"Elekon" centrifuge (Russia).

We checked validity of the results which we obtained during blood, urine, and hair samples analysis with spiked samples analysis (Table 2). A certain amount was added into an analyzed sample before it was prepared. Table 2 contains data on detection limits (LOD) calculated as per $3 \sigma$ criterion. Determination inaccuracy didn't exceed $15 \%$.

We analyzed standard blood samples SERONORM (Sero AS, Norway) blood L1 (LOT 1103128), L2 (LOT 1103129), L3 (LOT 1112691), urine samples Seronorm $^{\mathrm{TM}}$ (Sero AS, Norway) (LOT 0511545) and hair samples Reference Material in Human Hair (IAEA086,Vienna,Austria). Prior to the analysis, certified reference materials underwent the same preparation procedure as our experimental samples. Reference samples were 
analyzed after each 5 th actual sample. Data from the Table 3 prove there is an authentic similarity between detected and certified values.

Table 3

Certified and detected average mercury concentrations in standard blood, urine, and hair samples

\begin{tabular}{|l|c|c|c|}
\hline \multicolumn{1}{|c|}{ Level } & $\begin{array}{c}\text { Certified } \\
\text { value }\end{array}$ & $\begin{array}{c}\text { Detected } \\
\text { average val- } \\
\text { ue }\end{array}$ & $\begin{array}{c}\Delta, \\
\%\end{array}$ \\
\hline $\begin{array}{l}\text { Seronorm } \\
\mu \mathrm{g} / 1\end{array}$ & 39,8 & 39,3 & 1,2 \\
\hline $\begin{array}{l}\text { Seronorm } \text { urine }(n=5), \\
(n=5), \mu \mathrm{g} / 1\end{array}$ & 1,5 & 1,71 & 14,0 \\
\hline $\begin{array}{l}\text { Seronorm } \mathrm{L} 1 \\
(n=5), \mu \mathrm{g} / 1\end{array}$ & 16,0 & 17,3 & 8,1 \\
\hline $\begin{array}{l}\text { Seronorm blood L3 } \\
(n=4), \mu \mathrm{g} / 1\end{array}$ & 37,1 & 39,6 & 6,7 \\
\hline $\begin{array}{l}\text { Reference Material in } \\
\text { Human Hair }(n=10), \\
\mu \mathrm{g} / 1\end{array}$ & 0,573 & 0,635 & 10,8 \\
\hline
\end{tabular}

The suggested procedure was tested within LAMP international test program which was organized by the US Environmental Protection Agency, Centers for Diseases Control and Prevention (Atlanta, the USA), Results of blood samples examination in terms of mercury contents are given in Table 4.

The results of external quality control prove that the experiment results are quite satisfactory, as Z-index with its value as per modulus being $|Z| \leq 2$ is acceptable.
Table 4

Mercury contents in blood samples from LAMP (CDC, Atlanta, the USA)

\begin{tabular}{|c|c|c|c|}
\hline $\begin{array}{c}\text { Round/ code } \\
\text { of a sample }\end{array}$ & $\begin{array}{c}\text { Certified } \\
\text { value, } \mu \mathrm{g} / \mathrm{l}\end{array}$ & $\begin{array}{c}\text { Detected } \\
\text { value, } \mu \mathrm{g} / \mathrm{l}\end{array}$ & $Z$ - index \\
\hline $31 / 1402$ & 3,13 & 3,43 & 0,6 \\
\hline $31 / 1403$ & 8,00 & 8,6 & 0,7 \\
\hline $32 / 1404$ & 4,13 & 4,6 & 0,2 \\
\hline $32 / 1406$ & 2,57 & 3,7 & $-0,4$ \\
\hline $33 / 1407$ & 1,68 & 1,38 & $-0,6$ \\
\hline $33 / 1408$ & 6,24 & 5,58 & $-0,3$ \\
\hline $33 / 1409$ & 10,52 & 9,58 & $-0,2$ \\
\hline
\end{tabular}

We performed a metrological certification of the suggested procedure for determining mercury in blood, urine, and hair; this certification was accomplished in full conformity with the following regulatory documents: RMG 61-2010 State Standard R ISO 5725-1-2002, State Standard R ISO 5725-2-2002, State Standard R ISO 57253-2002, State Standard R ISO 5725-42002, State Standard R ISO 5725-5-2002 and State Standard R ISO 5725-6-2002 ${ }^{4}$.

This procedure for measuring mercury concentrations in blood, urine, and hair allows to obtain results with inaccuracies not higher than values given in Table 5 .

The developed ICP-MS-based procedure for determining mercury in biological media allows to determine the element in blood within $0.5-100 \mu \mathrm{g} / \mathrm{l}$ range of con

Table 5

Metrological characteristics of the procedure for mercury determination in a solution, $\mu \mathrm{g} / \mathrm{l}$

\begin{tabular}{|l|c|c|c|}
\hline $\begin{array}{c}\text { A component being deter- } \\
\text { mined and a range of measure- } \\
\text { ments in a solution }\end{array}$ & $\begin{array}{c}\text { Repeatability (relative } \\
\text { standard deviation in repeat- } \\
\text { ability), } \sigma \mathrm{r}, \%\end{array}$ & $\begin{array}{c}\text { Reproducibility (relative } \\
\text { standard deviation in repro- } \\
\text { ducibility) } \sigma_{R}, \%\end{array}$ & $\begin{array}{c}\text { Precision (relative inaccu- } \\
\text { racy limits at probability } \\
\mathrm{P}=0.95), \pm \delta, \%\end{array}$ \\
\hline $\begin{array}{l}\text { Blood, } \mu \mathrm{g} / \mathrm{l} \\
\text { from } 0.005 \text { to } 1.0 \text { inclusive }\end{array}$ & 9,19 & 13,23 & 29,42 \\
\hline $\begin{array}{l}\text { Urine, } \mu \mathrm{g} / 1 \\
\text { from } 0.04 \text { to } 1.0 \text { inclusive }\end{array}$ & 10,36 & 10,42 & 24,25 \\
\hline $\begin{array}{l}\text { Hair, } \mu \mathrm{g} / \mathrm{g} \\
\text { from } 0.1 \text { to } 1.0 \text { inclusive }\end{array}$ & 9,52 & 9,74 & 22,43 \\
\hline
\end{tabular}


Mercury contents in examined biological media

\begin{tabular}{|c|c|c|c|c|c|c|}
\hline Medium & Group & Perm region & $\begin{array}{c}\text { Canada } \\
{[16]}\end{array}$ & Russia [14] & $\begin{array}{c}\text { Germany } \\
{[6,17]}\end{array}$ & HBM-1 $[1,6]$ \\
\hline \multirow{2}{*}{$\begin{array}{l}\text { Blood, } \\
\mu \mathrm{g} / \mathrm{l}\end{array}$} & adults & - & $0,12-4,7$ & $0,89-2,39$ & $0,02-16$ & \multirow{2}{*}{5} \\
\hline & children & $0,02-1,2$ & $0,27-6,39$ & $0,2-0,43$ & $0,8-1,0$ & \\
\hline \multirow{2}{*}{ Urine, $\mu \mathrm{g} / 1$} & adults & $0,65-8,2$ & $0,2-3,5$ & $0,27-0,94$ & - & \multirow{2}{*}{7} \\
\hline & children & $0,45-0,8$ & $0,2-2,82$ & - & $0,4-0,8$ & \\
\hline Hair, $\mu \mathrm{g} / \mathrm{g}$ & adults & $0,29-0,49$ & - & $0,21-0,54$ & - & 1 \\
\hline
\end{tabular}

centrations with inaccuracy being equal to $29.4 \%$; in urine, within $0.4-100 \mu \mathrm{g} / 1$ with inaccuracy being $24.2 \%$; in hair, within $0.001-100 \mu \mathrm{g} / \mathrm{g}$ with inaccuracy being $22.4 \%$.

We detected the following limits of detection (LOD): $0.0015 \mu \mathrm{g} / \mathrm{l}$ for blood; $0.012 \mu \mathrm{g} / \mathrm{l}$ for urine; and $0.003 \mu \mathrm{g} / \mathrm{g}$, for hair.

Results and discussion. We tested the developed procedure as we examined patients from the in-patient department and the polyclinic of the Federal Scientific Center for Medical and Preventive Health Risk Management Technologies (Table 6). This Table contains data on mercury concentrations in biological media taken from people living in Canada, Russia, and Germany. We examined a group of children and detected that mercury contents in their blood and urine were lower than HBM-1. Mercury concentration in urine taken from exposed adults was higher than HBM-1. Mercury contents in urine taken from Rus-

\footnotetext{
${ }^{4}$ Gosudarstvennaya sistema obespecheniya edinstva izmerenii. Pokazateli tochnosti, pravil'nosti, pretsizionnosti metodik kolichestvennogo khimicheskogo analiza. Metody otsenki: rekomendatsii po mezhgosudarstvennoi standartizatsii [State system for ensuring the uniformity of measurements. Accuracy, trueness and precision measures of the procedures for quantitative chemical analysis. Methods of evaluation: Recommendations on interstate standardization]. CODEX: Electronic data fund for legal and technical regulatory documentation. Available at: $\mathrm{http}: / /$ docs.cntd.ru/document/1200094703 (23.01.2018).

State Standard R ISO 5725-1-2002. Tochnost' (pravil'nost' i pretsizionnost') metodov i rezul'tatov izmerenii. Ch. 1. Osnovnye polozheniya i opredeleniya [Accuracy (trueness and precision) of measurement methods and results. Part 1. General principles and definitions]. CODEX: Electronic data fund for legal and technical regulatory documentation. Available at: http://docs.cntd.ru/document/1200029975 (23.01.2018).

State Standard R ISO 5725-2-2002. Tochnost' (pravil'nost' i pretsizionnost') metodov i rezul'tatov izmerenii. Ch. 2. Osnovnoi metod opredeleniya povtoryaemosti i vosproizvodimosti standartnogo metoda izmerenii [Accuracy (trueness and precision) of measurement methods and results. Part 2. Basic method for the determination of repeatability and reproducibility of a standard measurement method]. CODEX: Electronic data fund for legal and technical regulatory documentation. Available at: http://docs.cntd.ru/

document/1200029976 (23.01.2018).

State Standard R ISO 5725-3-2002. Tochnost' (pravil'nost' i pretsizionnost') metodov i rezul'tatov izmerenii. Ch. 3. Promezhutochnye pokazateli pretsizionnosti standartnogo metoda izmerenii [Accuracy (trueness and precision) of measurement methods and results. Part 3. Intermediate measures of the precision of a standard measurement method]. Internet and law: Juridical company. Available at: http://www.internet-law.ru/gosts/gost/6182/ (23.01.2018).

State Standard R ISO 5725-4-2002. Tochnost' (pravil'nost' i pretsizionnost') metodov i rezul'tatov izmerenii. Ch. 4. Osnovnye metody opredeleniya pravil'nosti standartnogo metoda izmerenii [Accuracy (trueness and precision) of measurement methods and results. Part 4. Basic methods for the determination of the trueness of a standard measurement method]. CODEX: Electronic data fund for legal and technical regulatory documentation. Available at: http://docs.cntd.ru/document/1200029978 (23.01.2018).

State Standard R ISO 5725-5-2002 Tochnost' (pravil'nost' i pretsizionnost') metodov i rezul'tatov izmerenii. Ch. 5. Al'ternativnye metody opredeleniya pretsizionnosti standartnogo metoda izmerenii [Accuracy (trueness and precision) of measurement methods and results. Part 5. Alternative methods for the determination of the precision of a standard measurement method]. $\mathrm{CO}-$ DEX: Electronic data fund for legal and technical regulatory documentation. Available at: http://docs.cntd.ru/document/1200029979 (23.01.2018).

State Standard R ISO 5725-6-2002 Tochnost' (pravil'nost' i pretsizionnost') metodov i rezul'tatov izmerenii. Ch. 6. Al'ternativnye metody opredeleniya pretsizionnosti standartnogo metoda izmerenii [Accuracy (trueness and precision) of measurement methods and results. Part 6. Alternative methods for the determination of the precision of a standard measurement method]. $\mathrm{CO}$ DEX: Electronic data fund for legal and technical regulatory documentation. Available at: http://docs.cntd.ru/document/1200029980 (23.01.2018).
} 
sian population who were not exposed to this metal amounted to $0.27-0.94 \mu \mathrm{g} / \mathrm{l}$ [14]; mercury concentrations in urine taken from workers employed at an industrial enterprise amounted to $0.2-25.3 \mu \mathrm{g} / 1$ [15].

Mercury contents in urine taken from children whom we examined was at the same level as in children from Germany [6] .

Mercury contents in hair which we detected corresponded to all the literature data we managed to find $[1,6]$.

\section{Conclusions:}

1. The performed research gave us grounds to offer optimal conditions for a routine analysis of biological media aimed at determining overall mercury concentrations with ICP-MS. These conditions allow to determine the element in blood within $0.5-100 \mu \mathrm{g} / 1$ range of concentrations with inaccuracy being equal to $29.4 \%$; in urine, within $0.4-100 \mu \mathrm{g} / 1$ with inaccuracy being
$24.2 \%$; in hair, within $0.001-100 \mu \mathrm{g} / \mathrm{g}$ with inaccuracy being $22.4 \%$.

2. We achieved high repeatability of measurements in determining mercury contents in blood when we participated in LAMP international test program $(|Z| \leq 2)$.

3 . The developed ICP-MS based procedure for determining mercury in blood, urine, and hair was tested during examination of children and exposed adults. The obtained results are well in line with literature data.

4. Mercury contents in biological media taken from Perm region population who are not exposed to the metal do not exceed HBM-1 levels recommended by the WHO.

Funding. Our research was not granted any sponsors' support.

A conflict of interests. The authors state there is no conflict of interests.

\section{References}

1. Biomonitoring cheloveka: fakty i tsifry [Human biomonitoring: facts and figures]. Kopengagen, Regional office for Europe Publ., 2015. Available at: http: //www.euro.who.int/en/healthtopics/environment-and-health/health-impact-assessment/publications/2015/human-biomonitoringfacts-and-figures (18.01.2018).

2. Skal'nyi A.V., Rudakov I.A. Bioelementy v meditsine [Bioelements in medicine]. Moscow, Mir Publ., 2004, 272 p. (in Russian).

3. Tits N.U. Klinicheskoe rukovodstvo po laboratornym testam [Clinical guide on laboratory tests]. Moscow, Yunimed-press Publ., 2003, 960 p. (in Russian).

4. Toksikologicheskaya khimiya. Metabolizm i analiz toksikantov [Toxicological chemistry. Metabolism and analysis of toxicants]. In: N.I. Kaletina ed. Moscow, Izdatel'skaya gruppa GEOTAR-Media Publ., 2008, 1016 p. (in Russian).

5. Programma Organizatsii Ob"edinennykh Natsii po okruzhayushchei srede. UNEP (DTIE) /Hg/INC.2/6,2/9. 22 October 2010 [The United Nations Environmental Program. UNEP (DTIE) /Hg/INC.2/6,2/9. 22 October 2010]. DocPlayer.ru. Available at: http: //docplayer.ru/72077878Programma-organizacii-obedinennyh-naciy-po-okruzhayushchey-srede.html (18.01.2018) (in Russian).

6. Schulz Ch., Angerer J., Ewers U., Heudorf U., Wilhelm M. Revised and new reference values for environmental pollutants in urine or blood of children in Germany derived from the German Environmental Survey on Children 2003-2006 (GerESIV). Int. J. Hyg. Environ. Health, 2009, vol. 212, pp. 637-647.

7. Trace elements in human biological material. ALS Scandinavia. Available at: https: //www.alsglobal.se/mediase/pdf/reference_data_biomonitoring_120710.pdf (18.01.2018). 
8. Goulle J.P., Mahieu L., Castermant J. Metal and metalloid multi-elementary ICP-MS validation in whole blood, plasma, urine and hair: Reference values. Forensic Science International, 2005, vol. 153, pp. 39-44.

9. Karamova L.M., Larionova T.K., Basharova G.R. Kriterii ekologicheskoi bezopasnosti tyazhelykh metallov v krovi cheloveka [Criteria of ecologic safety for serum levels of heavy metals in humans]. Meditsina truda i promyshlennaya ekologiya, 2010, no. 6, pp. 21-23 (in Russian).

10. Ivanenko N.B., Ivanenko A.A., Nosova E.B. Opredelenie toksicheskikh i fonovykh soderzhanii rtuti $\mathrm{v}$ krovi atomno-absorbtsionnym metodom $\mathrm{s}$ elektrotermicheskoi atomizatsiei $\mathrm{i}$ Zeemanovskoi modulyatsionnoi polyarizatsionnoi korrektsiei fona [Determination of toxic and background mercury content in blood by graphite furnace atomic absorption spectrometry with Zeeman high-frequency polarization modulation background correction]. Vestnik SanktPeterburgskogo universiteta. Fizika i khimiya, 2010, no. 4, pp. 97-104 (in Russian).

11. Pogarev S.E., Ryzhov V.V., Dreval' T.V., Mash'yanov N.R. Ispol'zovanie Zeemanovskogo spektrometra dlya opredeleniya rtuti v moche [Use of Zeemann's spectrometer to determine mercury in urine]. Ekologicheskaya khimiya, 1994, vol. 3, pp. 227 (in Russian).

12. Ivanenko N.B., Ganeev A.A., Solov'ev N.D. Opredelenie mikroelementov v biologicheskikh zhidkostyakh (Obzor) [Determination of trace elements in biological fluids]. Zhurnal analiticheskoi khimii, 2011, vol. 66, no. 9, pp. 900-915 (in Russian).

13. Ivanenko N.B., Solov'ev N.D., Ivanenko A.A., Moskvin L.N. Opredelenie khimicheskikh form mikroelementov v biologicheskikh ob"ektakh [Trace element speciation analysis of biological media]. Analitika i kontrol', 2012, vol. 16, no. 2, pp. 108-133 (in Russian).

14. Egorov A.I., Il'chenko I.N., Lyapunov S.M., Marochkina E.B., Okina O.I., Ermolaev B.V., Karamysheva T.V. Primenenie standartizovannoi metodologii biomonitoringa cheloveka dlya otsenki prenatal'noi ekspozitsii k rtuti [Application of a standardized human biomonitoring methodology to assess prenatal exposure to mercury]. Gigiena i sanitariya, 2014, vol. 93, no. 5, pp. 10-18 (in Russian).

15. Zibarev E.V., Chashchin M.V., Nikonova S.M., Kusraeva Z.S., Kuz'min A.V., Ellingsen D.G., Thomassen Y. Otsenka biomarkerov ekspozitsii k svarochnomu aerozolyu [Evaluating biomarkers of exposure to electric welding aerosol]. Meditsina truda i promyshlennaya ekologiya, 2010, no. 4, pp. 14-17 (in Russian).

16. Results of the Canadian Health Measures Survey Cycle 1 (2007-2009). Government of Canada. Available at: https://www.canada.ca/en/health-canada/services/environmental-workplacehealth/reports-publications/environmental-contaminants/report-human-biomonitoringenvironmental-chemicals-canada-health-canada-2010.html (18.01.2018).

17. Heitland P., Koster H.D. Biomonitoring of 37 trace elements in blood samples from inhabitants of northern Germany by ICP - MS. J. of Trace Elements in Medicine and Biology, 2006, vol. 20 , pp. 253-262.

Ulanova T.S., Stenno E.V., Veikhman G.A., Nedoshitova A.V. Methodical and practical aspects related to total mercury determination in whole blood, urine and hair with mass-spectrometry with inductively coupled plasma. Health Risk Analysis, 2018, no. 2, pp. 119-128. DOI: 10.21668/health.risk/2018.2.14.eng

Received: 26.02 .2018

Accepted: 17.06.2018

Published: 30.06.2018 